\author{
ACTA MYCOLOGICA \\ Vol. 43 (2): 173-179 \\ 2008
}

\title{
Fungi isolated from phyllosphere of fodder galega (Galega orientalis)
}

\author{
BOŻENA CWALINA-AMBROZIAK ${ }^{1}$ and STANISEAW SIENKIEWICZ ${ }^{2}$
}

${ }^{1}$ Department of Phytopathology and Entomology, University of Warmia and Mazury

Prawocheńskiego 17, PL-10-722 Olsztyn, bambr@uwm.edu.pl

${ }^{2}$ Department of Agriculture Chemistry and Environment Protection, University of Warmia and Mazury Oczapowskiego 8, PL-10-722 Olsztyn

Cwalina-Ambroziak B., Sienkiewicz S.: Fungi isolated from phyllosphere of fodder galega (Galega orientalis). Acta Mycol. 43 (2): 173-179, 2008.

The object of the experiment was fodder galega (Galega orientalis Lam.) cultivated in 2001-2003 as field crop on three plots: 1 . without fertilization, 2. $40 \mathrm{~kg} \mathrm{P}_{2} \mathrm{O}_{5} \times \mathrm{ha}^{-1}$ and $80 \mathrm{~kg}$ $\mathrm{K}_{2} \mathrm{O} \times \mathrm{ha}^{-1}, 3.80 \mathrm{~kg} \mathrm{P}_{2} \mathrm{O}_{5}^{-1} \times$ ha and $160 \mathrm{~kg} \mathrm{~K}_{2} \mathrm{O} \times \mathrm{ha}^{-1}$.

During the dry and warm vegetation season of 2002 almost two times fewer isolates were obtained from the leaves than in 2003 that was the most abundant in fungi.

Yeasts-like fungi (30\% of the total number of isolates) and saprotrophic fungi with dominated species: Acremonium strictum (8.5\%), genus Epicoccum (7.8\%), Humicola (9.5\%) and Penicillium $(18.9 \%)$ were the fungi most frequently populating the leaves of galega. The share of pathogens in the total number of isolates obtained from the phyllosphere was $10.6 \%$. They were represented by fungi of Ascochyta spp., Botrytis cinerea, genus Fusarium, Phoma medicaginis and Sclerotinia sclerotiorum. Reduction by 1.9 to $4.6 \%$ in the number of fungi isolated from the phyllosphere of galega without fertilization as compared to galega cultivated in combinations with fertilization was recorded. Generally, the smallest number of pathogens was recovered from galega fertilized with $40 \mathrm{~kg} \mathrm{P}_{2} \mathrm{O}_{5} \times \mathrm{ha}^{-1}$ and $80 \mathrm{~kg} \mathrm{~K}_{2} \mathrm{O} \times \mathrm{ha}^{-1}$. B. cinerea most frequently populated galega in combination without fertilization, genus Fusarium fungi in combination without fertilization and with fertilization with $80 \mathrm{~kg} \mathrm{P}_{2} \mathrm{O}_{5}^{-1} \times$ ha and $160 \mathrm{~kg}$ $\mathrm{K}_{2} \mathrm{O} \times$ ha $^{-1}$, while Ascochyta spp. were isolated from galega with fertilization only.

Key words: pathogenic fungi, saprotrophic fungi, phyllosphere of fodder galega, mineral fertilization 


\section{INTRODUCTION}

Fodder galega, a perennial legume plant with fine seeds, is relatively immune to viral infections as we learn from reports (Kegler, Spaar 1996; Valkonnen 1993). Among fungal pathogens infesting this plant, similar to Fabaceae belonging to the same family, alfalfa and clover, Botrytis cinerea as well as species of Ascochyta and Fusarium should be mentioned (Cwalina-Ambroziak et al. 1999; Gorsen et al. 1994; Leath, Hower 1993; Leath et al. 1994). The above-indicated species of fungi were isolated from the phyllosphere of galega by Cwalina-Ambroziak and Koc (2005); they populated galega cultivated as single crop more frequently than galega cultivated in a mix with brome grass. Mineral fertilization can also influence the composition of fungal community, which was proven during studies on mycological assessment of rhizosphere, rhizoplane and roots of plants belonging to the above-indicated family (Cwalina-Ambroziak, Majchrzak 2000; Deb, Bora 1996).

The laboratory studies conducted aimed at analysis of the fungal community populating the phyllosphere of fodder galega cultivated under conditions of diversified mineral fertilization.

\section{MATERIALS AND METHODS}

Fodder galega was cultivated in 2001-2003 at the Agricultural Experimental Enterprise in Bałcyny as crop field on good wheat complex soil on three plots of 1 ha each:

1. without fertilization

2. $40 \mathrm{~kg} \mathrm{P}_{2} \mathrm{O}_{5} \times \mathrm{ha}^{-1}$ and $80 \mathrm{~kg} \mathrm{~K}_{2} \mathrm{O} \times \mathrm{ha}^{-1}\left(17.46 \mathrm{~kg} \mathrm{P} \times \mathrm{ha}^{-1}\right.$ and $66.45 \mathrm{~kg}$ $\mathrm{K} \times \mathrm{ha}^{-1}$ )

3. $80 \mathrm{~kg} \mathrm{P}_{2} \mathrm{O}_{5}^{-1} \times$ ha and $160 \mathrm{~kg} \mathrm{~K}_{2} \mathrm{O} \times \mathrm{ha}^{-1}\left(34.92 \mathrm{~kg} \mathrm{P} \times \mathrm{ha}^{-1}\right.$ and $132.90 \mathrm{~kg}$ $\mathrm{K} \times$ ha $^{-1}$ ). Fertilization with $\mathrm{P}_{2} \mathrm{O}_{5}$ (superphosphate) and $\mathrm{K}_{2} \mathrm{O}$ (potassium salt) was applied before sowing.During flowering of galega samples of 20 leaves were collected from plants growing on individual plots from three locations selected at random. At the laboratory fungi were isolated from the collected plant material according to the methodology by Chruściak (1974). From the basal part of the leave a fragment of $1 \mathrm{~cm}^{2}$ of leaf blade was cut out and shaken in flasks filled with $200 \mathrm{ml}$ of sterile water. From the suspension of microorganisms prepared in this way $0.2 \mathrm{ml}$ was transferred into Petri dishes and covered with glucose and potato medium PDA with Bengal rose and streptomycin. The fungi growing on the PDA medium were transferred after 5 days of incubation at $22^{\circ} \mathrm{C}$ on PDA slants for identification of species according to the keys (Arx 1970; Booth 1971; Ellis 1971; Nelson et al. 1983; Skirgiełło et al. 1979). Colonies of yeasts-like fungi were counted. Analysis of variance using the $T$-Duncan test was carried out to determine the influence of mineral reutilization and sampling time on the numbers of fungi most often isolated from leaves of galega (STATISTICA ${ }^{\circledast} 62001$ software package). 


\section{RESULTS AND DISCUSSION}

As a result of three-year studies 1289 fungal isolates among which yeasts-like fungi dominated $(30 \%)$ were recovered from leaves of fodder galega. The other fungi were represented by 19 species and nonsporulating cultures. Saprotrophic fungi were recovered from leaves in large numbers among which genus Penicillium species were the most frequent (Tab. 1). The other identified fungal species were of genus Humicola (9.5\%), and Acremonium strictum (8.5\%), Epicoccum purpurascens $(7.8 \%)$, Alternaria alternata $(4.2 \%)$ and Cladosporium cladosporioides $(3.5 \%)$. Chruściak (1974), Madej (1997) and Wozniakowskaja (1962) classify those fungi as microorganisms commonly populating the leaves of many plant species. Additionally those authors inform that yeasts-like fungi populate young leaves of plants first. In this study pathogenic fungi Botrytis cinerea (4.9\%), genus Fusarium (3.2\%), Ascochyta (2.1\%), Phoma medicaginis $(0.3 \%)$ and Sclerotinia sclerotiorum ( $0.5 \%)$ were recovered in lower numbers than saprotrophic fungi. Three Fusarium species were identified: F. avenaceum, F. culmorum and F. equiseti. Those pathogens are considered in literature (Gorsen et al. 1994; Leath et al. 1994) the major causes of diseases in fine seed legumes such as clover and alfalfa.

The structure of fungal community in the phyllosphere of fodder galega formed under the influence of application of mineral fertilizers and weather conditions during the consecutive years of study. The largest numbers of fungi were recovered from the phyllosphere of fodder galega in the combination without fertilization and

Table 1

Fungi isolated from phyllosphere of fodder galega (\% of isolates)

\begin{tabular}{|l|c|c|c|c|c|c|c|c|c|}
\hline \multirow{2}{*}{ Species } & \multicolumn{3}{|c|}{2001} & \multicolumn{3}{c|}{2002} & \multicolumn{3}{c|}{2003} \\
\cline { 2 - 11 } & $\mathrm{K}$ & $\begin{array}{c}40 \\
\mathrm{P}\end{array}$ & $\begin{array}{c}80 \\
\mathrm{P}\end{array}$ & $\mathrm{K}$ & $\begin{array}{c}40 \\
\mathrm{P}\end{array}$ & $\begin{array}{c}80 \\
\mathrm{P}\end{array}$ & $\mathrm{K}$ & $\begin{array}{c}40 \\
\mathrm{P}\end{array}$ & $\begin{array}{c}80 \\
\mathrm{P}\end{array}$ \\
\hline Acremonium strictum W. Gams & 15.1 & 11.1 & 4.4 & 30.3 & 5.3 & 7.8 & & 1.5 & 1.9 \\
\hline Alternaria alternata (Fr.) Keissler & 2.0 & 0.7 & & 0.7 & 6.3 & 3.9 & 9.1 & 8.4 & 5.0 \\
\hline Ascochyta spp. & & 2.2 & 5.8 & & 4.2 & 4.9 & & 2.0 & 1.9 \\
\hline Botryodiplodia spp. & & & & & 3.2 & & & & \\
\hline Botrytis cinerea Pers. & 7.9 & 3.7 & 4.4 & 2.0 & 4.2 & 1.0 & 9.1 & 3.9 & 6.3 \\
\hline Cladosporium cladosporioides (Fres.) de Vries & 7.2 & 5.2 & 6.6 & 3.3 & 3.2 & 5.9 & 0.7 & 1.5 & \\
\hline Epicoccum purpurascens & 5.3 & 10.4 & 8.8 & 4.6 & 19.0 & 9.8 & 5.2 & 5.9 & 6.9 \\
\hline Fusarium avenaceum (Fr.) Sacc. & 1.3 & & 0.7 & 7.2 & 1.1 & 12.8 & 0.7 & & \\
\hline Fusarium culmorum (W.G.Sm.) Sacc. & & 1.5 & & 1.3 & 3.2 & & 0.7 & & \\
\hline Fusarium equiseti (Corda) Sacc. & & & & & 1.1 & 2.9 & & & \\
\hline Helminthosporium sativum Pammel & & & & & & & 0.7 & & \\
\hline Humicola fuscoatra Traaen & 7.2 & 7.4 & 3.7 & 1.3 & & 2.0 & 0.7 & 6.4 & 5.0 \\
\hline Humicola grisea Traaen & & 3.0 & 4.4 & 7.9 & 3.2 & 6.9 & 10.3 & 10.8 & \\
\hline Mortierella alpina Peyronel & 0.7 & & 0.7 & & 5.3 & & & & 1.3 \\
\hline Mucor circinelloides van Tieghem & & 1.5 & & & & & 1.3 & 2.0 & 0.6 \\
\hline Mucor hiemalis Wehmer & 0.7 & & 0.7 & & & & 5.8 & 1.5 & 2.5 \\
\hline Penicillium spp. & 11.2 & 23.7 & 17.5 & 9.2 & 19.0 & 20.6 & 18.1 & 31.0 & 16.4 \\
\hline Phoma medicaginis Malbr. et Roum. & & & & 0.7 & 3.2 & & & & \\
\hline Sclerotinia sclerotiorum (Lib.) de Bary & & & & & & & & 1.0 & 2.5 \\
\hline Non sporulating fungi & 3.3 & 11.1 & 6.6 & 0.7 & 4.2 & 4.9 & 3.9 & 1.5 & 1.3 \\
\hline Yeast-like fungi & 38.2 & 18.5 & 35.8 & 30.9 & 14.7 & 16.7 & 33.7 & 22.6 & 48.4 \\
\hline Total (number of isolates) & 152 & 135 & 137 & 152 & 95 & 102 & 154 & 203 & 159 \\
\hline
\end{tabular}

Explanatations: $\mathrm{K}$ - control, $40 \mathrm{P}-40 \mathrm{~kg} \mathrm{P}_{2} \mathrm{O}_{5} \times$ ha $^{-1}$ and $80 \mathrm{~kg} \mathrm{~K}_{2} \mathrm{O} \times \mathrm{ha}^{-1}, 80 \mathrm{P}-80 \mathrm{~kg} \mathrm{P}_{2} \mathrm{O}_{5} \times \mathrm{ha}^{-1}$ and $160 \mathrm{~kg} \mathrm{~K}_{2} \mathrm{O} \times \mathrm{ha}^{-1}$. 
the smallest from combination with fertilization with $80 \mathrm{~kg} \mathrm{P}_{2} \mathrm{O}_{5} \times \mathrm{ha}^{-1}$ and $160 \mathrm{~kg}$ $\mathrm{K}_{2} \mathrm{O} \times \mathrm{ha}^{-1}$. However, pathogens were the least frequently isolated from the combination with fertilization with $40 \mathrm{~kg} \mathrm{P}_{2} \mathrm{O}_{5} \times \mathrm{ha}^{-1}$ and $80 \mathrm{~kg} \mathrm{~K}_{2} \mathrm{O} \times \mathrm{ha}^{-1}$. Fusarium spp. and Botrytis cinerea populated leaves of galega cultivated on all plots (Fig. 1a, b, c). $B$. cinerea populated galega in combination without fertilization most frequently (6.3\%), with a significant difference in numbers as compared to both combinations with fertilization (Tab. 2). Fungi responsible for wilting of plants colonized the leaves of galega to a similar extent in both plots without fertilization and the one with the highest fertilization rate. Fungi of genus Ascochyta were not recovered from plants cultivated without fertilization while their share in the total number of fungi recovered from combinations with fertilization was $2.5 \%$ (lower fertilization) and $4.0 \%$ (higher fertilization).

At the same time a larger number of saprotrophic fungi of genera Epicoccum and Penicillium as well as order Mucorales was obtained from plants in combinations with mineral fertilization $-39.5 \%$ of the total number of isolates $\left(40 \mathrm{~kg} \mathrm{P}_{2} \mathrm{O}_{5} \times \mathrm{ha}^{-1}\right.$ and $\left.80 \mathrm{~kg} \mathrm{~K}_{2} \mathrm{O} \times \mathrm{ha}^{-1}\right)$ and $28.4 \%\left(80 \mathrm{~kg} \mathrm{P}_{2} \mathrm{O}_{5} \times \mathrm{ha}^{-1}\right.$ and $\left.160 \mathrm{~kg} \mathrm{~K}_{2} \mathrm{O} \times \mathrm{ha}^{-1}\right)$ as compared to the control combination $-20.7 \%$ of isolates. Some authors indicate the stimulating influence of mineral fertilization on development of saprotrophic fungi in communities of soil fungi of galega (Cwalina-Ambroziak, Majchrzak 2000) and other Fabaceae crops (Deb, Bora 1996).

At the same time a larger number of saprotrophic fungi of genera Epicoccum and Penicillium as well as order Mucorales was obtained from plants in combinations with mineral fertilization $-39.5 \%$ of the total number of isolates $\left(40 \mathrm{~kg} \mathrm{P}_{2} \mathrm{O}_{5} \times \mathrm{ha}^{-1}\right.$ and $\left.80 \mathrm{~kg} \mathrm{~K}_{2} \mathrm{O} \times \mathrm{ha}^{-1}\right)$ and $28.4 \%\left(80 \mathrm{~kg} \mathrm{P}_{2} \mathrm{O}_{5} \times \mathrm{ha}^{-1}\right.$ and $\left.160 \mathrm{~kg} \mathrm{~K}_{2} \mathrm{O} \times \mathrm{ha}^{-1}\right)$ as

Table 2

Most isolated fungi from phyllosphere of fodder galega (number of isolates) during investigation period

\begin{tabular}{|c|c|c|c|c|}
\hline Species & Mean for: & 2001 & 2002 & 2003 \\
\hline \multirow{2}{*}{ Acremonium strictum } & years & $14.67 \mathrm{a}$ & $19.67 \mathrm{a}$ & $2.00 \mathrm{~b}$ \\
\hline & combination & $\mathrm{K}-23.00 \mathrm{a}$ & $\begin{array}{c}40 \mathrm{P}-7.67 \mathrm{~b} \\
-5.67 \mathrm{~b}\end{array}$ & $80 \mathrm{P}$ \\
\hline \multirow[t]{2}{*}{ Alternaria alternata } & years & $1.33 \mathrm{~b}$ & $3.67 \mathrm{~b}$ & $13.00 \mathrm{a}$ \\
\hline & combination & $\mathrm{K}-6.00 \mathrm{~b}$ & $\begin{array}{c}40 \mathrm{P}-8.00 \mathrm{a} \\
-4.00 \mathrm{c}\end{array}$ & $80 \mathrm{P}$ \\
\hline \multirow[t]{2}{*}{ Botrytis cinerea } & years & $7.67 \mathrm{ab}$ & $2.67 \mathrm{c}$ & $10.67 \mathrm{a}$ \\
\hline & combination & $\mathrm{K}-9.67 \mathrm{a}$ & $\begin{array}{c}40 \mathrm{P}-5.67 \mathrm{~b} \\
-5.67 \mathrm{~b}\end{array}$ & $80 \mathrm{P}$ \\
\hline \multirow[t]{2}{*}{ Epicoccum spp. } & years & $11.33 \mathrm{a}$ & $11.67 \mathrm{a}$ & $10.33 \mathrm{a}$ \\
\hline & combination & $\mathrm{K}-7.67 \mathrm{c}$ & $\begin{array}{c}40 \mathrm{P}-14.67 \mathrm{a} \\
-11.00 \mathrm{ab}\end{array}$ & $80 \mathrm{P}$ \\
\hline \multirow[t]{2}{*}{ Fusarium spp. } & years & $1.67 \mathrm{~b}$ & $11.33 \mathrm{a}$ & $0.67 \mathrm{~b}$ \\
\hline & combination & $\mathrm{K}-5.67 \mathrm{a}$ & $\begin{array}{c}40 \mathrm{P}-2.33 \mathrm{~b} \\
-5.67 \mathrm{a}\end{array}$ & $80 \mathrm{P}$ \\
\hline \multirow[t]{2}{*}{ Humicola spp. } & years & $12.00 \mathrm{bc}$ & $8.67 \mathrm{c}$ & $20.00 \mathrm{a}$ \\
\hline & combination & $\mathrm{K}-14.00 \mathrm{ab}$ & $\begin{array}{c}40 \mathrm{P}-17.33 \mathrm{a} \\
-9.33 \mathrm{bc}\end{array}$ & $80 \mathrm{P}$ \\
\hline \multirow[t]{2}{*}{ Penicillium spp. } & years & $24.33 \mathrm{~b}$ & $17.67 \mathrm{c}$ & $39.00 \mathrm{a}$ \\
\hline & combination & $K-19.67 b$ & $\begin{array}{c}40 \mathrm{P}-37.67 \mathrm{a} \\
-23.67 \mathrm{~b}\end{array}$ & $80 \mathrm{P}$ \\
\hline
\end{tabular}

Explanations as in Table 1. 
Fungal colonies isolated from phyllosphere
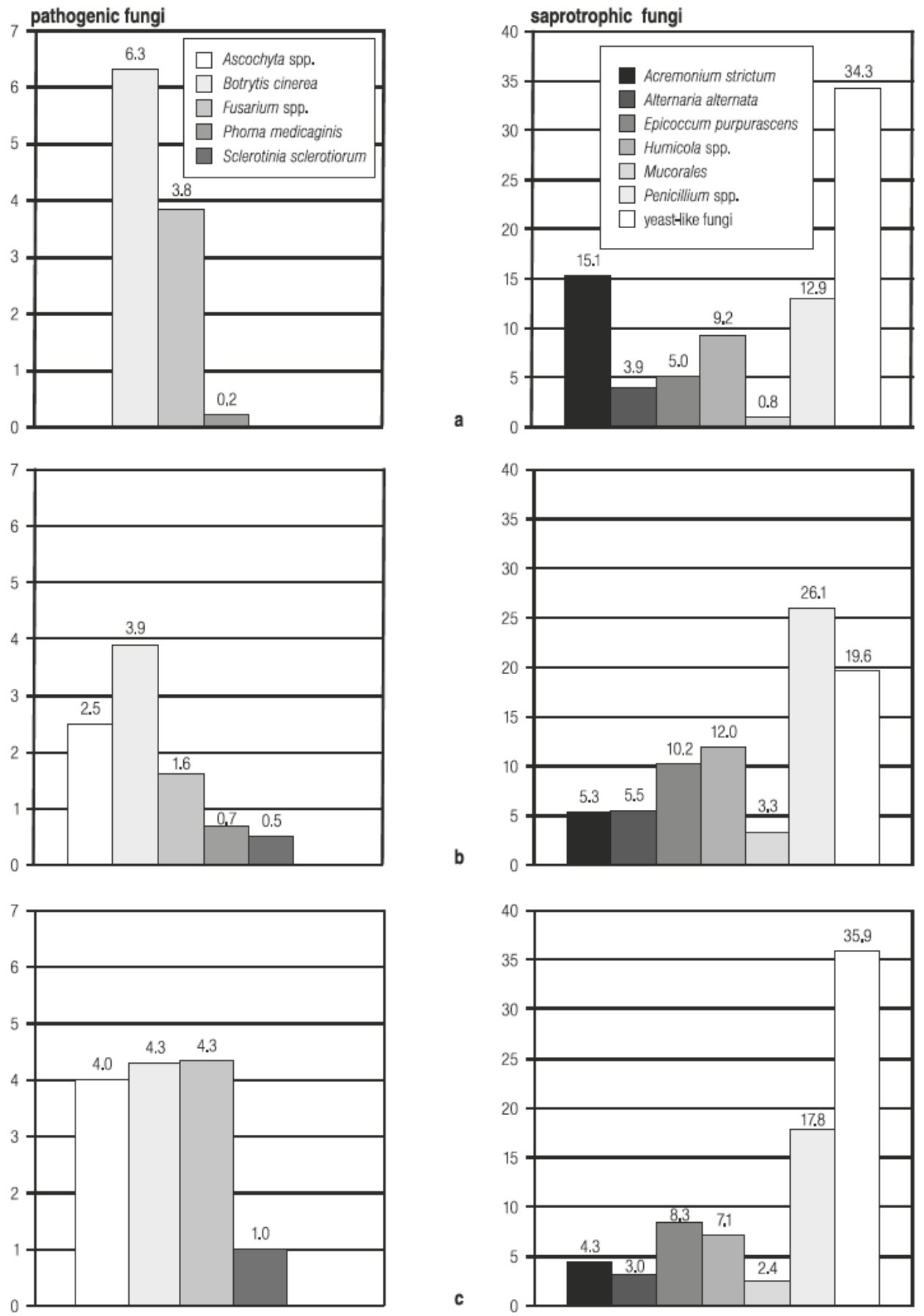

Fig. 1. Percentage of fungi isolated from phyllosphere of fodder galega: $\mathrm{a}$ - control, $\mathrm{b}-\mathrm{fer}-$ tilization $40 \mathrm{~kg} \mathrm{P}_{2} \mathrm{O}_{5} \times \mathrm{ha}^{-1}$ and $80 \mathrm{~kg} \mathrm{~K}_{2} \mathrm{O} \times \mathrm{ha}^{-1}$, c - fertilization $80 \mathrm{~kg} \mathrm{P}_{2} \mathrm{O}_{5} \times \mathrm{ha}^{-1}$ and $160 \mathrm{~kg} \mathrm{~K}_{2} \mathrm{O} \times \mathrm{ha}^{-1}$. 
compared to the control combination $-20.7 \%$ of isolates. Some authors indicate the stimulating influence of mineral fertilization on development of saprotrophic fungi in communities of soil fungi of galega (Cwalina-Ambroziak, Majchrzak 2000) and other Fabaceae crops (Deb, Bora 1996).

Analyzing the fungal communities of the phyllosphere of fodder galega during individual vegetation seasons the largest number of isolates were recovered in 2001 and $2003-32.9$ and $40 \%$ of the total number of colonies respectively. B. cinerea was among the most frequently recovered pathogens during those years. Gorsen et al. (1994) consider vegetation seasons characterized by high precipitations and moderate temperatures as favorable for the causing agent of grey mould and such conditions existed during the above seasons of study. The lowest number of fungi was recovered from leaves during hot and dry summer of 2002 (27.1\%). Among the pathogens recovered during that season fungi of genus Fusarium dominated and their number was significantly higher than during the other two years of study.

\section{CONCLUSIONS}

1. Mineral ferilization reduced the total number of fungi colonizing the phyllosphere of fodder galega.

2. Ferilization had a varied effect on the development of pathogens. The largest numbers of $B$. cinerea were recovered from galega in treatment without ferilization, in contrast to the genus Fusarium and Ascochyta.

\section{REFERENCES}

Arx von J. A. 1970. The genera of fungi sporulating in pure culture. Verlag von J. Cramer.

Booth T. C.1971. The genus Fusarium. Commonwealth Mycological Institute Kew Surrey, England.

Chruściak E. 1974. Mikoflora fyllosfery. Acta Mycol. 10 (1): 173-180.

Cwalina-Ambroziak B., Czajka W., Wojnowska T. 1999. Research on the health state of goats rue (Galega orientalis Lam.). Acta Acad. Agricult. Techn. Olst. Natur. Sc., 2: 17-26.

Cwalina-Ambroziak B., Koc J. 2005. Grzyby zasiedlające nadziemne organy roślin rutwicy wschodniej (Galega orientalis Lam.) uprawianej w siewie czystym i w mieszance ze stokłosą bezostną (Bromus inermis Leyss.). Acta Agrobot. 58 (1): 125-133.

Cwalina-Ambroziak B., Majchrzak B. 2000. The structure of fungal population from Galega orientalis root system formed as the result of fertilization. Acta Mycol. 35 (2): 311-321.

Deb B., Bora K. N. 1996. Effect of chemical fertilizer on the rhizosphere mycoflora and nodulation of pea plant. Environ. Ecol. 14 (4): 747-751.

Ellis M. B. 1971. Dematiaceous, Hyphomycetes. CMI, KEW, Surrey.

Gorsen B. D. Smith S. R., Platford R. G. 1994. Botrytis cinerea blossom blight of alfalfa on the Canadian prines. Pl. Dis. 78 (12): 1218.

Kegler H., Spaar D. 1996. On the virus susceptibility of Galega orientalis Lam. Arch. Phytopath. Plant Protect. 30 (3): 187-190.

Leath K. T., De Gregorio R. E., Ashley R. A. 1994. Foliar blight of bigflower vetch caused by Ascochyta fabae f. sp. vicia. Pl. Dis. 78 (6): 637-639.

Leath K. T., Hower A. A. 1993. Interaction of Fusarium oxysporum f. sp. medicaginis with feeding activity of flover root curculio larvae in alfalfa. Pl. Dis. 77 (8): 799-802.

Madej T. 1997. Grzyby następczo zasiedlające liście ziemniaka. Ochr. Rośl. 11: 6-7.

Nelson P. E., Toussoun T.A., Marasas W. F. O. 1983. Fusarium species. The Pensylvania State University Press, University Park, London.

Skirgiełlo A., Zadara M., Ławrynowicz M. 1979. Flora polska. Grzyby (Mycota). 10: Glonowce (Phycomycetes). Pleśniakowe (Mucorales). Instytut Botaniki PAN, Warszawa-Kraków. 
Valkonnen J. P. T. 1993. Resistance to six viruses in the legume goat's rue (Galega orientalis Lam.). Ann. Appl. Biol. 123 (2): 309-314.

Wozniakowskaja J. M. 1962. Epiphytic yeast-organism. Mikrobiologia 31: 616-622.

\section{Grzyby wyizolowane z fyllosfery rutwicy wschodniej (Galega orientalis)}

Streszczenie

W doświadczeniu poletkowym $\mathrm{w}$ Bałcynach uprawiano rutwicę wschodnią w następujących obiektach: 1. bez nawożenia, 2. $40 \mathrm{~kg} \mathrm{P}_{2} \mathrm{O}_{5} \times \mathrm{ha}^{-1}$ i $80 \mathrm{~kg} \mathrm{~K}_{2} \mathrm{O} \times \mathrm{ha}^{-1}, 3.80 \mathrm{~kg} \mathrm{P}_{2} \mathrm{O}_{5}^{-1} \times$ ha i $160 \mathrm{~kg} \mathrm{~K}_{2} \mathrm{O} \times \mathrm{ha}^{-1}$. Założeniem przeprowadzonych badań w aspekcie fitopatologicznym było określenie zbiorowiska grzybów zasiedlających fyllosferę roślin. W tym celu w okresie przed kwitnieniem rutwicy do laboratorium pobierano próby zbiorcze liści z roślin w poszczególnych kombinacjach. Izolacje grzybów przeprowadzono zgodnie z metodyką Chruściak (1974).

Liście rutwicy wschodniej były zasiedlone przez 1289 izolatów grzybów reprezentowanych przez 19 gatunków oraz przez grzyby drożdżopodobne i kultury niezarodnikujące. Najliczniej wyosobniono grzyby w 2003 roku (616 izolatów), a najmniej licznie w 2002 roku (349). Największy udział wśród ogółu izolatów miały grzyby drożdżopodobne (30\% ogółu izolatów), mniejszy grzyby saprotroficzne z rodzajów: Penicillium (18.9\%), Humicola (9.5\%), Epicoccum (7.8\%) oraz gatunki: Acremonium strictum (8.5\%), Alternaria alternata (4.2\%) i Cladosporium cladosporioides (3.5\%). Rzadziej izolowano z liści gatunki patogeniczne Botrytis cinerea (4.9\%) oraz z rodzaju Fusarium (3.2\%) i Ascochyta (2.1\%). Najmniej izolatów otrzymano $\mathrm{z}$ liści rutwicy w kombinacji z nawożeniem $80 \mathrm{~kg} \mathrm{P}_{2} \mathrm{O}_{5}^{-1} \times$ ha i $160 \mathrm{~kg} \mathrm{~K}_{2} \mathrm{O} \times$ ha $^{-1}$, jednak najczęściej izolowano tu patogeniczne gatunki z rodzaju Ascochyta. Nie wyizolowano tego grzyba z rutwicy uprawianej w kontroli, w przeciwieństwie do najliczniej występującego gatunku B. cinerea. 